\title{
Analisis Pengaruh Bauran Pemasaran Terhadap Pembeli Produk Indomie Di Kecamatan Kabupaten Kampar
}

\author{
ZAINAL ABIDIN \\ Sekolah Tinggi Ilmu Ekonomi Bangkinang \\ Jl. A. Rahman Saleh No. 54A Bangkinang Kota \\ E-mail : abiiidin.zainal1959@gmail.com
}

\begin{abstract}
This study aims to determine whether there is an influence of marketing mix factors such as price, distribution, and promotion of Indomie product purchases in Kampar District. purchasing decisions are actions of consumers to buy or not to a product. Each producer must run a variety of strategies so that consumers decide to buy their products. Hypothesis testing using Chi Square with a total sample of 100 people sampled. Sampling uses incidental sampling technique that is by selecting anyone who is in the research object. Based on the results of hypothesis analysis and the relationship between variables, price variables, distribution and promotion partially and simultaneously significantly influence consumer decisions in buying products, the most dominant factor influencing Indomie purchasing decisions is promotion and distribution variables with contingency values of 0.727 .
\end{abstract}

Keywords: Marketing Mix, Purchasing Decisions

Perekonomian sekarang ini menganut system ekonomi pasar, sehingga keberhasilan suatu perusahaan akan ditentukan oleh pasarnya. Oleh karena itu strategi pemasaran menjadi ujung tombak kegiatan perusahaan, karena pasarlah yang akan memberikan keuntungan bagi perusahaan.

Indomie adalah salah satu produk mie instant yang sudah banyak di kenal masyarakat hingga ke pelosok pedesaan. Semakin banyaknya produk mie instant yang beredar dipasaran, produk Indomie tentunya semakin mendapat banyak persaingan. Tetapi, nampaknya Indomie merupakan produk yang masih menempati posisi terkuat dipasar. Berdasarkan pengamatan sementara, banyak masyarakat yang mengkonsumsi Indomie dibandingkan mie instant lainnya.

Masih kuatnya pasar Indomie dibandingkan pasar mie instant lainnya, tentu tidak lepas dari strategi pemasaran yang dijalankan oleh PT. Indofood sebagai produsen Indomie. Keberhasilan pemasaran juga tidak bisa lepas dari perilaku konsumennya, karena bagaimanapun rangsangan yang ditimbulkan oleh strategi pemasaran suatu perusahaan akan terkait dengan sikap konsumen itu sendiri dalam keputusan pembeliannya.

Masyarakat Kecamatan Kampar merupakan masyarakat yang sedang berkembang. Perkembangan ini disebabkan oleh adanya perkembangan kota Pekanbaru sebagai Ibu Kota Provinsi Riau dan Kota Bangkinang sebagai Ibu Kota Kabupaten Kampar, dimana Kecamatan Kampar terletak diantara dua kota tersebut.

Kemajuan Kota Pekanbaru membawa dampak kemajuan (perubahan) terhadap masyarakat kecamatan Kampar, salah satunya adalah pola konsumsi yang dahulunya memakan nasi sekarang banyak yang mengkonsumsi mie instant sebagai penggantinya. Hal ini kemungkinan besar disebabkan oleh adanya kepraktisan dalam memasak dan menyajikan, sehingga dapat memenuhi tuntutan kebutuhan baik kebutuhan atas rasa lapar maupun kebutuhan penghematan waktu.

Pemasaran adalah suatu proses sosial dan.manajerial dimana individu dan kelompok mendapatkan apa yang mereka 
butuhkan dan inginkan dengan menciptakan, menawarkan, dan mempertukarkan produk yang bernilai dengan pihak lain (Kotler, 1996:13). Pengertian tersebut memiliki konsep inti yang antara lain berupa :
a. Kebutuhan (needs), keinginan (wants), dan permintaan (demands).
b. Produk (barang, jasa dan gagasan)
c. Nilai, biaya dan kepuasan
d. Pertukaran dan transaksi
e. Hubungan dan jaringan Konsumen atau pelanggan merupakan pihak yang sangat penting untuk pijakan pemasar dalam melakukan kegiatan pemasaran. Hal yang demikian menunjukkan bahwa konsumen/pelanggan perlu diperhatikan dalam rangka segala hal untuk kepentingan pemasaran suatu produk. Pijakan pemasaran adalah adanya kebutuhan dan keinginan konsumen, kemudian pemasaran memproduksi produk yang sesuai kebutuhan dan keinginan konsumen dengan memberikan nilai, biaya, dan kepuasan yang ada pada konsumen tersebut, sehingga akan menimbulkan pertukaran dan transaksi, dan supaya tidak kehilangan pelanggan, pemasaran harus berbentuk pemasaran hubungan atau jaringan.

Menurut Kotler (1998:37), bauran pemasaran meliputi produk, harga, distribusi dan promosi. Dalam strategi bauran pemasaran, keempat aspek tersebut perlu diperhitungkan secara terpadu supaya saling menunjang dalam upaya mencapai hasil penjualan yang optimum. Aspek tersebut meliputi empat $\mathrm{P}$, yaitu Product (produk), Price (harga), Place (tempat), dan Promotion (promosi).

\section{Produk}

Produk adalah segala sesuatu yang dapat ditawarkan ke pasar untuk memenuhi keinginan dan kebutuhan seseorang. Dilihat dari segi pemasar, produk memiliki lima tingkat produk yang keseluruhannya membentuk suatu hirarki nilai pelanggan, yaitu :

a. Tingkat paling dasar adalah manfaat ini (Core benefit), yaitu jasa atau

Jurnal Daya Saing (Vol. 5, No. 3 Okober 2019) manfaat dasar yang sesungguhnya dibeli pelanggan

b. Tingkat kedua adalah produk dasar (basic product), yaitu produk yang dapat memberikan jasa atau manfaat pelanggan

c. Tingkat ketiga adalah produk yang diharapkan (expected product), yaitu suatu set atribut dan kondisi yang biasanya diharapkan dan setujui pembeli ketika mereka membelinya.

d. Tingkat keempat adalah produk yang ditingkatkan (augmented product), yaitu yang memenuhi keinginan pelanggan dan melampaui harapannya

e. Tingkat kelima adalah produk potensial (potential product), yaitu yang mencakup semua peningkatan dan transpormasi yang akhirnya akan dialami produk tersebut dimasa depan.

2. Harga

Harga ini penting, karena melalui harga produk itu akan bisa menguntungkan dan juga merugikan. Untuk menetapkan harga, pemasar perlu memperhatikan faktor-faktor yang mempengaruhi kepekaan harga pembeli. Menurut Nagle (Kotler, 1998:111), harga pembeli dipengaruhi oleh faktor-faktor : Nilai-nilai unik; Kesadaran atas produk pengganti; Perbandingan yang sulit; Pengeluaran total; Manfaat akhir; Biaya yang dibagi; Investasi tertanam; Kualitas harga; Persediaan; Distribusi.

Agar produknya sampai ketangan pembeli, produsen memerlukan saluran distribusi, atau dikenal juga dengan saluran pemasaran atau saluran perdagangan. Dalam menetapkan strategi saluran pemasaran (distribusi), pemasar perlu memahami tingkat hasil (service output level) yang diinginkan pelanggan. Menurut Kotler (1998:146), saluran distribusi memuat lima hasil pelayanan, yaitu :

a. Ukuran lot, yaitu jumlah unit yang saluran pemasaran perbolehkan 
untuk dibeli satu pelanggan setiap kali pembelian

b. Waktu tunggu, yaitu rata-rata waktu pelanggan menunggu untuk menerima barang

c. Kenyamanan tempat, yaitu tingkat kemudahan yang disediakan saluran pemasaran bagi pelanggan untuk membeli produk tersebut

d. Variasi produk, yaitu luasnya keragaman yang diberikan oleh saluran pemasaran

e. Pelayanan pendukung, yaitu pelayanan tambahan yang disediakan oleh saluran tersebut.

3. Promosi

Promosi merupakan strategi pemasaran dalam upaya meningkatkan pemasarannya. Dalam strategi ini, ada tiga alat yang dapat digunakan yaitu periklanan, promosi penjualan, dan hubungan masyarakat (Kotler, 1998:235). Periklanan adalah segala bentuk penyajian nonpersonal dan promosi ide, barang atau jasa oleh suatu sponsor tertentu yang memerlukan pembayaran. Periklanan dapat dilakukan melalui berbagai media massa seperti TV, media cetak ataupun radio.

Pembelian yang dilakukan oleh pembeli, melalui suatu proses. Proses pembelian dimulai saat pembeli menemui suatu masalah atau kebutuhan. Kebutuhan dapat ditimbulkan oleh rangsangan internal maupun eksternal. Kebutuhan atas rasa lapar merupakan masalah yang timbul dari internal. Tetapi dapat juga seseorang yang melewati sebuah warung dan melihat mie instant terpajang, menjadikan rangsangan rasa laparnya. Kebutuhan yang sudah muncul dalam diri seseorang tersebut akan menimbulkan keinginan. Keinginan ini akan mendorong untuk melakukan pencarian informasi tentang produk yang dapat memenuhi kebutuhannya.

Menurut Kotler (1998:171), sumber informasi untuk itu digolongkan kedalam empat kelompok, yaitu :

a. Sumber pribadi : keluarga, teman, tetangga, kenalan b. Sumber komersial : iklan, wiraniaga, penyalur, kemasan, pajangan

c. Sumber publik : media massa, organisasi konsumen pemeringkat

d. Sumber pengalaman : media massa, pengkajian, dan pemakaian produk

Setelah mengumpulkan dan mendapatkan informasi, konsumen mengetahui produk-produk sejenis yang bersaing beserta keistimewaannya. Selanjutnya terjadilak proses evaluasi alternatif. Proses evaluasi dapat terjadi : pertama, konsumen berusaha memenuhi kebutuhan; kedua, konsumen mencari manfaat tertentu dari produk; ketiga, konsumen memandang setiap produk sebagai sekumpulan atribut dengan kemampuan yang berbeda-beda dalam memberikan manfaat yang dicari untuk memuaskan kebutuhan tersebut.

Adapun hipotesis pada penelitian ini adalah : "Diduga produk, harga, tempat dan promosi mempunyai pengaruh yang signifikan terhadap keputusan konsumen dalam membeli produk Indomie. Diantara faktor-kator tersebut, promosi merupakan faktor yang dominan.

\section{METODE}

Populasi Penelitian ini adalah pembeli produk Indomie yang berdomisili di kecamatan kabupaten Kampar. Sampel diambil secara Insidential sampling, yaitu orang-orang yang membeli produk Indomie di warung/kedai yang ada di air tiris. Sampel diambil sebanyak 100 orang guna memenuhi ukuran jumlah sampel yang layak untuk keperluan inferensial (Suharsimi, 1996)

Data yang terkumpul akan dianalisis secara diskriptif maupun secara inferensial. Analisis deskriptif dipergunakan untuk mengetahui alas an konsumen dalam membeli produk Indomie. Sedangkan analisis inferensial digunakan untuk mengetahui ada tidaknya pengaruh faktor strategi bauran pemasaran terhadap keputusan pembelian produk Indomie. 
Analisis inferensial menggunakan uji Chi kuadrat dalam taraf signifikansi $5 \%$, melalui tabel kontingensi langkah-langkah yang dilakukan dalam analisis inferensial ini yaitu :

1) Mencari rata-rata pendapatan pembeli produk Indomie (X) dan simpangan bakunya (SD), kemudian menentukan tingkatan pendapatan dengan cara mengelompokkannya kedalam tiga kelompok, yaitu :

a. Pendapatan rendah pendapatan terendah X-ISD

b. Pendapatan sedang X-ISD sampai XISD

c. Pendapatan tertinggi X-ISD sampai Pendapatan tertinggi

2) Membuat tabel kontingensi untuk tingkat pendapatan dan strategi bauran pemasaran

3) Menghitung tabel frekuensi senyatanya $\left(\mathrm{n}_{\mathrm{ij}}\right)$ untuk masing-masing sel tabel kontingensi

4) Menghitung frekuensi yang diharapkan $\left(\mathrm{e}_{\mathrm{ij}}\right)$ untuk masing-masing sel tabel kontingensi

5) Menghitung nilai $X^{2}$ observasi dengan rumus (Djarwanto dan Subagyo, 1996:244) :

$$
\begin{array}{r}
X^{2}=\sum_{i=1}^{r} \sum_{j=1}^{k} \frac{\left(n_{i j}-e_{i j}\right)^{2}}{e_{i j}} \\
e_{i j}=\frac{\left(n_{i}\right)\left(n_{j}\right)}{n}
\end{array}
$$

$\mathrm{r} \quad=\quad$ Banyaknya kelompok tingkat pendapatan (banyaknya baris)

$\mathrm{k}=$ Banyaknya faktor strategis bauran pemasaran (banyaknya kolom)

$\mathrm{n}_{\mathrm{ij}}=$ frekuensi hasil pengamatan (senyatanya) padasel ke $\mathrm{ij}$

$\mathrm{e}_{\mathrm{ij}}=$ frekuensi $\quad$ yang diharapkan pada sel ke ij $\mathrm{j}=$ Kolom ke

6) Membandingkan $X^{2}$ observasi dengan $\mathrm{X}^{2}$ tabel
7) Mengambil kesimpulan dengan criteria :

a. Bila X2 observasi > X2 tabel, ada pengaruh yang berarti

b. Bila X2 observasi $\leq$ tabel, tidak ada pengaruh yang berarti.

\section{HASIL}

Karakteristik responden pada penelitian ini adalah rata-rata penghasilan 1 bulan. Berdasarkan penelitian karakteristik demografi respnden yang perlu dan penting untuk diperhatikan oleh pihak distributor terhadap angka frekuensi kejadian yang tinggi, hal ini penting untuk mendapat perhatian, guna merumuskan kebijakankebijakan yang berkaitan dengan segmentasi pasar untuk meningkatkan volume penjualan, sehingga diharapkan memberikan masukan kepada produsen untuk dapat mengantisipasi masalahmasalah yang berhubungan dengan penjualan Indomie.

Analisis Variabel Independen

Keterkaitan dengan Produk

1. Variabel produk yang dihubungkan dengan keputusan konsumen. Dari variabel produk responden/konsumen yang paling banyak memberikan pernyataan Sangat Tidak Setuju (STS) 41 orang $(41 \%)$.

2. Variabel harga yang dihubungkan dengan keputusan konsumen. Dari variabel harga responden/konsumen yang paling banyak memberikan pernyataan Sangat Tidak Setuju (STS) 41 orang $(41 \%)$.

3. Variabel distribusi yang dihubungkan dengan keputusan konsumen. Dari variabel distribusi responden/konsumen memberikan pernyataan (STS, TS, S) masingmasing sebanyak 26 orang (26\%) dan ada 22 orang (22\%) responden yang menyatakan sangat setuju.

4. Variabel promosi yang dihubungkan dengan keputusan konsumen. Dari variabel promosi responden/konsumen yang paling 
banyak memberikan pernyataan Sangat Tidak Setuju (STS) 41 orang $(41 \%)$.

Analisis Pengujian Hipotesis dan Hubungan Antara Variabel. Untuk mengetahui tingkatan pendapatan rata-rata, penulis mengelompokkan dalam tiga kelompok dengan rumus :

$\underline{\mathrm{Pt}-\mathrm{Pr}}$

3

Keterangan :

$\mathrm{Pt}=$ Pendapatan tinggi

$\operatorname{Pr}=$ Pendapatan rendah

$$
\begin{aligned}
\frac{\mathrm{Pt}-\mathrm{Pr}}{3}=\quad \text { Rp. } 1.500 .000-\text { Rp. } 200.000 \\
=\frac{\text { Rp. } 1.300 .000}{3} \\
=\text { Rp. } \quad 433.000
\end{aligned}
$$

Sebagai interval sebagai berikut :

1. Rp. 200.000 s/d Rp. 633.000 (Pendapatan rendah)

2. Rp. 634.000 s/d Rp. 1.067 .000 (Pendapatan menengah)

3. Rp. 1.068 .000 s/d Rp. 1.500 .000 (Pendapatan tinggi)

Jadi untuk mengetahui responden untuk menjawab variabel (produk, harga, distribusi dan promosi) sebagai berikut :

Tabel 1.: Kontingensi Pengaruh Bauran Pemasaran Terhadap Pembeli Produk Indomie

\begin{tabular}{|l|l|l|l|l|l|l|}
\hline \multirow{2}{*}{ Pendapatan } & \multicolumn{3}{|l|}{ Faktor yang mempengaruhi } & \multirow{2}{*}{$\begin{array}{l}\text { Jumla } \\
\text { h }\end{array}$} \\
\cline { 3 - 7 } & $\begin{array}{l}\text { Prod } \\
\text { uk }\end{array}$ & Harga & $\begin{array}{l}\text { Disrtib } \\
\text { usi }\end{array}$ & $\begin{array}{l}\text { Prom } \\
\text { osi }\end{array}$ & \\
\hline 1 & Tinggi & 2 & 0 & 5 & 5 & 12 \\
\hline 2 & Sedang & 6 & 5 & 16 & 15 & 42 \\
\hline 3 & Rendah & 6 & 15 & 15 & 12 & 45 \\
\hline Jumlah & 14 & 20 & 34 & 32 & 100 \\
\hline
\end{tabular}

Hasil perhitungan

Chi Kuadrat $=26,785$

$\mathrm{DF}=6$

Prob $=0,000139$

Chi Kuadrat $\quad(6: 0,05)=12,597$
Dari hasil analisis menunjukkan bahwa Chi Kuadrat (hitung lebih besar dari Chi Kuadrat) tabel, ini berarti hipotesis yang diajukan diterima, yakni produk, harga, distribusi dan promosi mempunyai pengaruh yang signifikan terhadap keputusan konsumen.

Dari keempat variabel tersebut ternyata faktor-faktor yang paling dominan mempengaruhi konsumen membeli produk Indomie adalah variabel distribusi dengan nilai contingency $=0,727$. Untuk lebih jelasnya dapat dilihat dalam tabel berikut :

\begin{tabular}{|l|l|l|l|l|}
\hline No. & Variabel & $\begin{array}{l}\text { Chi } \\
\text { Kuadr } \\
\text { at } \\
\text { Hitung }\end{array}$ & DF & $\begin{array}{l}\text { Koefisien } \\
\text { Contingenc } \\
\text { y }\end{array}$ \\
\hline 1 & Produk & 70,905 & 9 & 0,644 \\
\hline 2 & Harga & 88,085 & 9 & 0,684 \\
\hline 3 & Distribusi & $\begin{array}{l}111,97 \\
7\end{array}$ & 9 & 0,727 \\
\hline 4 & Promosi & 73,942 & 9 & 0,625 \\
\hline
\end{tabular}

\section{PEMBAHASAN}

Dari uraian di atas, dapat dibahasn bahwa tujuan pemasaran (marketing) adalah menciptakan nilai bagi pihak yang berkepentingan, dan pihak yang berkepentingan yang paling utama adalah pelanggan.

Strategi yang popular dalam pemasaran adalah bauran pemasaran (marketing mix) yang mencakupi produk, harga, distribusi, dan promosi. Konsumen adalah hakim terakhir dengan arti menjadi penentu tentang apa yang harus diproduksi / dihasilkan perusahaan dan berapa harga yang peru ditentukan. Demikian dengan distribusi dan promosinya.

Variabel produk yang paling banyak memberikan pernyataan sangat tidak setuju 41 orang (41\%). Variabel harga yang paling banyak memberikan pernyataan tidak setuju 41 orang $(41 \%)$. Variabel distribusi yang paling banyak memberikan pernyataan sangat tidak setuju 26 orang $(26 \%)$.

Variabel promosi yang paling banyak memberikan pernyataan sangat tidak setuju 41 orang (41\%). Dari hasil analisis hipotesis dan hubungan antara 
variabel ternyata semua variabel berpengaruh secara signifikan terhadap keputusan dalam pembeli produk Indomie. Faktor yang paling dominan mempengaruhi konsumen membeli produk Indomie adalah variabel promosi dan distribusi dengan nilai congtingency 0,727 .

\section{SIMPULAN}

Berdasarkan hasil analisis hipotesis dan hubungan antara variabel, variabel harga, distribusi dan promosi secara parsial dan simultan berpengaruh secara signifikan terhadap keputusan konsumen dalam membeli produk, faktor yang paling dominan mempengaruhi keputusan pembelian Indomie adalah variabel promosi dan distribusi dengan nilai contingency 0,727 .

\section{DAFTAR RUJUKAN}

Craven, D.W. (1996). Strategi marketing. New Jersey, Ricard D Irwin Ine.

Djarwanto Dim Subagyo, Pangestu. 1996. Statistik Unduktif, Yogyakarta BPFE

Dramesta dan Handoko, H. (1997). Manajemen pemasaran, analisis perilaku konsumen ed. I. Yogyakarta BPFE.

Freddy Rangkuti, Riset Pemasaran. Jakarta, PT. Gramedia Pustaka Utama

Gito Sudarno, I (2000). Manajemen pemasaran, Fakultas Ekonomi. UGM Yogyakarta. BPFE.

Goriskeraf (1980). Komposisi. Jakarta Nusa Indah

Hermawan Kerta Jaya (1997). Marketing plus 2000. Siasat memenangkan persaingan global. PT. Gramedia Pustaka Utama.

Halimah W Kadarsan. (1995). Keuangan pertanian dan pembiayaan perusahaan. Jakarta : PT. Gramedia Pustaka Utama.
Indriyo Gito Sudarno. (1994). Manajemen pemasaran. Yogyakarta BPFE

J. Supranto. (1997). Pengukuran tingkat kepuasan pelanggan. Rineka cipta Jakarta

Keegan, Waren J. (1996). Manajemen pemasaran global, edisi bahasa Indonesia yang direvisi, terjemahan Alexander Sindaro. Jakarta.

Kotler, Philips. J. (1998). Manajemen pemasaran, analisis, perencanaan, implementasi, dan control. Edisi bahasa Indonesia terjemahan Hendra Teguh dan Ronny A Rusli. Jakarta, Simon dan Schuter (Asia) Pte. Ltd.

Kotler P dan Clarke, Roberts N. (1987). Marketing for healt care manajemen, Englewood. New Jersey, Prantice - Hall Inc

Suharsimi Arikunto (1996). Manajemen marketing. Jakarta, Liberty

Suharsimi Arikunto (1998). Prosedur penelitian. Jakarta, Rineka Cipta.

Supranto. J. (1997). Pengukuran tingkat kepuasan pelanggan untuk menaikkan pangsa pasar. Jakarta, Rineka Cipta

Sujana (1982). Mode statistic. Tarsito Bandung

Tjiptono (1997). Strategi pemasaran. Yogyakarta, Andi Offset

Urban G.L and Star. SH. (1991). Advanced marketing strategi.

Wahyudi, D.H (1998). Pengukuran tingkat kepuasan konsumen dengan survegual instrument. Wahana 1 (Agustus) 9-17. 